DOI: https://doi.org/10.32838/2523-4803/70-2-53

УДК 338.48:502.333

\title{
Лiтвак О.A.
}

кандидат економічних наук,

доцент кафедри екології та природоохоронних технологій,

Національний університет кораблебудування імені адмірала Макарова

\section{Litvak Olga}

Admiral Makarov National University of Shipbuilding

\section{ФОРМУВАННЯ ІНФРАСТРУКТУРИ ЕКОЛОГІЧНОГО ТУРИЗМУ В МИКОЛАЇВСЬКІЙ ОБЛАСТІ}

\begin{abstract}
Стаття присвячена дослідженню особливостей формування інфраструктури екологічного туризму в Миколаӥвській області. Наведено перелік показників, щяо визначають стан та рівень розвитку рекреаційної інфраструктури екологічного туризму в регіоні. Потенційним ресурсом розвитку екологічного туризму в Миколаївській області є наявність національних природних та регіональних ландшафтних парків. Визначено чинники, щчо обумовлюють розвиток екологічного туризму та його інфраструктури в зонах рекреацї природоохоронних територій. Проведено аналіз структури колективних засобів розмішування у сфері туристичного бізнесу в Миколаївській області, визначено найбільш прийнятні засоби розмішування для прихильників екологічного туризму за співвідношенням «ціна - якість». Визначено головні чинники, щзо гальмують розвиток рекреаційної інфраструктури екологічного туризму на природоохоронних територіях регіону. Обгрунтовано пріоритетні завдання розвитку інфраструктури екологічного туризму в Миколаївській області, які спрямовані на соиіально-економічний розвиток регіону та збереження екологічної рівноваги.

Ключові слова: екологічний туризм, рекреачійна інфраструктура, природно-заповідний фонд, національні природні парки, регіональні ландиафтні парки, сільський (зелений) туризм, екоготелі.
\end{abstract}

Постановка проблеми. Процеси урбанізації та стійке погіршення якості навколишнього середовища є головними причинами зростання інтересу до екологічного туризму. 3 розвитком екологічного туризму пов'язана зміна моделі природокористування, орієнтована не тільки на економічний і соціальний розвиток, але й на охорону природного та культурного надбання. При цьому має забезпечуватися баланс таких інтересів:

- природоохоронні (охорона біологічного й ландшафтного різноманіття, унікальних природних об'єктів від масових туристичних потоків);

- економічні (отримання коштів від відвідування туристами природних територій);

- соціальні (надання людям можливості повноцінного духовного та фізичного відпочинку в природних умовах, проведення екологічної освітньої роботи 3 туристами, виховання любові до природи).

Проблема використання потенціалу екологічного туризму дуже тісно пов'язана з формуванням та розвитком його інфраструктури. Сутність проблеми полягає в тому, щоби за збереження в непорушеному вигляді природних територій забезпечити доступ до них туристів. При цьому слід розуміти, що екологічний туризм не орієнтований на підтримку великих туристичних потоків і насамперед пов'язаний з відвідуванням національних природних та регіональних ландшафтних парків, природних заповідників [1].
Важливими та актуальними є раціональне використання, збереження природно-культурної спадщини, створення сприятливої екологічної обстановки на територіях національних природних парків та заповідників. Формування й розвиток туристської інфраструктури на територіях та об'єктах природно-заповідного фонду можуть відбуватися тільки за умови природоохоронних обмежень та у спеціально виділених для цього функціональних зонах.

Аналіз останніх досліджень і публікацій. Теоретико-методологічні дослідження процесу розвитку та організації екологічного туризму висвітлені у працях О.О. Бейдика, В.І. Вишневського, О.Ю. Дмитрука, Ю.В. Зінько, І.Т. Русєва, Л.В. Теодорович та інших науковців. Подальших досліджень потребують питання оцінювання потенційних можливостей, сучасного стану, проблем та перспектив розвитку екологічного туризму на територіях окремих регіонів для обгрунтування пріоритетів і стратегічних шляхів розвитку всього туристичнорекреаційного комплексу та вдосконалення рекреаційної інфраструктури з урахуванням екологічних вимог.

Формулювання цілей статті. Метою статті $є$ аналіз особливостей формування інфраструктури екологічного туризму в Миколаївській області та визначення перспектив подальшого розвитку екологічного туризму в регіоні.

Виклад основного матеріалу. Відповідно до Положення про рекреаційну діяльність у межах терито- 
рій та об’єктів природно-заповідного фонду України рекреаційна інфраструктура - це сукупність засобів забезпечення організації та здійснення рекреаційної діяльності (шляхи сполучення, заклади розміщення й харчування, транспортні засоби, еколого-освітні центри, елементи рекреаційного благоустрою тощо) [2].

Оцінити стан та рівень розвитку рекреаційної інфраструктури екологічного туризму в регіоні можна за допомогою таких показників:

- щільність засобів розміщення туристів, що відповідають екологічним вимогам;

- транспортна доступність;

- різноманітність та атрактивність природних ландшафтів;

- щільність музеїв (краєзнавчих, природно-історичних, музеїв-заповідників);

- відсоток площі природно-заповідних територій у загальній площі регіону;

- наявність у структурі національних природних парків і природних заповідників відділів екологічної освіти, природних музеїв, екологічних візит-центів, екологічних стежок і туристичних маршрутів екологічного спрямування.

Миколаївська область має вигідне геополітичне положення для розвитку екологічного туризму. Сприятливими факторами $є$ виходи до Чорного моря, Ягорлицької затоки та Дніпробузького лиману. Площа природно-заповідного фонду становить $3,07 \%$ від загальної площі області. На території Миколаївської області створено 141 об'єкт природно-заповідного фонду фактичною площею 75 487,74 га, з яких 8 є об'єктами загальнодержавного значення, зокрема природний заповідник, два національних природних парки, зоопарк, лісовий заказник та пам'ятки природи, 133 є об'єктами місцевого значення, зокрема п'ять регіональних ландшафтних парків, ландшафтні, лісові, гідрологічні заказники, пам'ятки природи, паркипам'ятники садово-паркового мистецтва (табл. 1) [3].

В системі природно-заповідного фонду парки відіграють особливу роль, оскільки наділені не тільки природоохоронною, але й рекреаційною функціями.
Законом України «Про природно-заповідний фонд України» передбачені в територіальній структурі національних природних парків зона регульованої рекреації та зона стаціонарної рекреації.

До зони регульованої рекреації належать території, які мають рекреаційне, еколого-освітне, культурновиховне та науково-пізнавальне значення. У цій зоні $\epsilon$ екологічні стежки, а також маршрути екологічного туризму та постійних екскурсій. Водночас тут забороняються рубки лісу головного користування, промислове рибальство й мисливство. Зона стаціонарної рекреації слугує для розміщення готелів, кемпінгів, інших об'єктів рекреаційної інфраструктури [4].

Розвиток екологічного туризму на рекреаційних ділянках природоохоронних територій обумовлений такими чинниками:

- наявність різноманітних, цікавих, унікальних об'єктів природи;

- організація екскурсійної діяльності підготовленим персоналом;

- прокладання туристичних маршрутів та екологічних стежок;

- облаштування оглядових зупинок у зонах регульованої рекреації зі встановленням контейнерів для сміття, громадських вбиральнь, тіньових навісів, місць для розкладання багаття;

- наявність системи моніторингу, що дає змогу регулювати рекреаційні навантаження;

- можливості розвивати найрізноманітніші форми екологічного туризму, зокрема активного, пізнавального, наукового;

- можливість організовувати семінари, науковопрактичні конференції, студентські практики, що сприяють екологічній освіті та вихованню людей різних соціальних груп і віку.

Потенційним ресурсом розвитку екологічного туризму в Миколаївській області є наявність національних природних парків та регіональних ландшафтних парків. Об'єктами рекреації в межах природно-заповідного фонду $\epsilon$ національні природні парки «Бузький Гард», «Білобережжя Святослава»;

Таблиця 1

Території та об’єкти природно-заповідного фонду Миколаївської області станом на 1 січня 2018 р.

\begin{tabular}{|c|c|c|c|c|}
\hline \multirow{3}{*}{$\begin{array}{c}\text { Категорія об'єктів } \\
\text { природно-заповідного фонду }\end{array}$} & \multicolumn{4}{|c|}{ Об'єкти природно-заповідного фонду } \\
\hline & \multicolumn{2}{|c|}{ загальнодержавного значення } & \multicolumn{2}{|c|}{ місцевого значення } \\
\hline & кількість, од. & площа, га & кількість, од. & площа, га \\
\hline Природні заповідники & 1 & 3010,65 & - & - \\
\hline Біосферні заповідники & 1 & 2741,0 & - & - \\
\hline Національні природні парки & 2 & 41361,28 & - & - \\
\hline Регіональні ландшафтні парки & - & - & 5 & 39345,2 \\
\hline Заказники, усього & 1 & 1782,0 & 54 & 10657,92 \\
\hline Пам’ятки природи & 1 & 11,0 & 43 & \\
\hline Заповідні урочища & - & - & 13 & 3656,7 \\
\hline $\begin{array}{l}\text { Парки-пам’ятки садово-паркового } \\
\text { мистецтва }\end{array}$ & 1 & 28,0 & 18 & 186,3 \\
\hline Зоологічні парки & 1 & 18,48 & & \\
\hline Разом & 8 & 48952,41 & 133 & 54121,08 \\
\hline
\end{tabular}


регіональні ландшафтні парки «Гранітно-степове Побужжя», «Кінбурнська коса», «Тилігульський», «Приінгульський»; лісовий заказник загальнодержавного значення «Рацинська дача» [5].

Задля розвитку еколого-туристичної інфраструктури на об'єктах природно-заповідного фонду області підтримуються розбудова екскурсійної діяльності, прокладання еколого-туристичних стежок та облаштування оглядових зупинок. Спеціалістами розроблено туристичні маршрути екологічного спрямування, зокрема «Екологічний Південний Буг», «Зелене розмаїття гранітно-степового Побужжя», «Екзотика Приінгулля», «Місто давніх греків - Ольвія», «Найцікавіші об’єкти регіонального ландшафтного парку «Приінгульський» [6].

Слід також виділити чотири види екологічного туризму, які $є$ перспективними для природних умов Миколаївської області, такі як науковий туризм, пізнавальний туризм, пригодницький туризм, подорожі в межах природоохоронних та сільських територій (рис. 1).

Туристичні маршрути екологічного спрямування часто передбачають пересування туристів пішки уздовж природних коридорів (узбережь річок, каналів та озер, лісових доріг і стежок) або з використанням немоторизованих засобів транспорту (на велосипеді, байдарці, верхи на коні). На відміну від масового туризму, екологічні маршрути припускають активне спілкування туристів 3 місцевими жителями, проведення екскурсій, майстер-класів 3 народних ремесл, фестивалів, дегустацій страв регіональної кухні, продаж сувенірної продукції, розміщення й харчування на базі зелених садиб [7].

Розвиток екологічного туризму в Миколаївській області передбачає використання вже наявного потенціалу рекреаційної інфраструктури, а саме санаторіїв, будинків відпочинку, пансіонатів, турбаз, екологічних стежок та маршрутів різної протяжності й ступеня складності.
Одними з найважливіших складових частин рекреаційної інфраструктури є засоби розміщення туристів. За даними статистичних спостережень загальна кількість колективних засобів розміщування у сфері туристичного бізнесу в області станом на 1 січня 2018 р. складає близько 271 одиниць, з яких 114 об'єктів належать юридичним особам, а 157 - фізичним особам підприємцям [8]. Останнім часом простежується тенденція зменшення кількості засобів розміщення, що належать юридичним особам. При цьому з кожним роком збільшується кількість готелів, баз відпочинку й туристичних баз, власниками яких $є$ фізичні особи підприємці (табл. 2). Такі засоби розміщування переважно невеликі, мають меншу місткість, але пропонують туристам повний спектр основних і додаткових послуг, вартість яких нижче.

За результатами аналізу структури колективних засобів розміщування у сфері туристичного бізнесу в Миколаївській області треба відзначити, що найбільшу питому вагу мають бази відпочинку $(61,6 \%)$, друге місце посідають готелі (22,1\%). Частка туристських баз та студентських літніх таборів складає 5,2\%. На наш погляд, туристські бази та літні студентські табори є найбільш прийнятними для прихильників екологічного туризму. Також вартість послуг на туристичних базах нижче, ніж у готелях, і становить у середньому від 165,7 до 179,9 грн. за один людино-день.

Найбільші фактичні витрати на перебування туристів в об'єктах надання туристичних послуг у Миколаївській області виявлено у гуртожитках для приїжджих, кемпінгах, пансіонатах відпочинку й готелях. Найменшими є витрати на проживання у хостелах (120,0 грн.). Динаміку фактичних витрат на проживання у готелях та спеціалізованих засобах розміщення (людино-день) у Миколаївській області та Україні наведено на рис. 2.

За результатами дослідження показників вартості перебування відпочиваючих і туристів у колективних засобах розміщування за останні роки виявлено, що

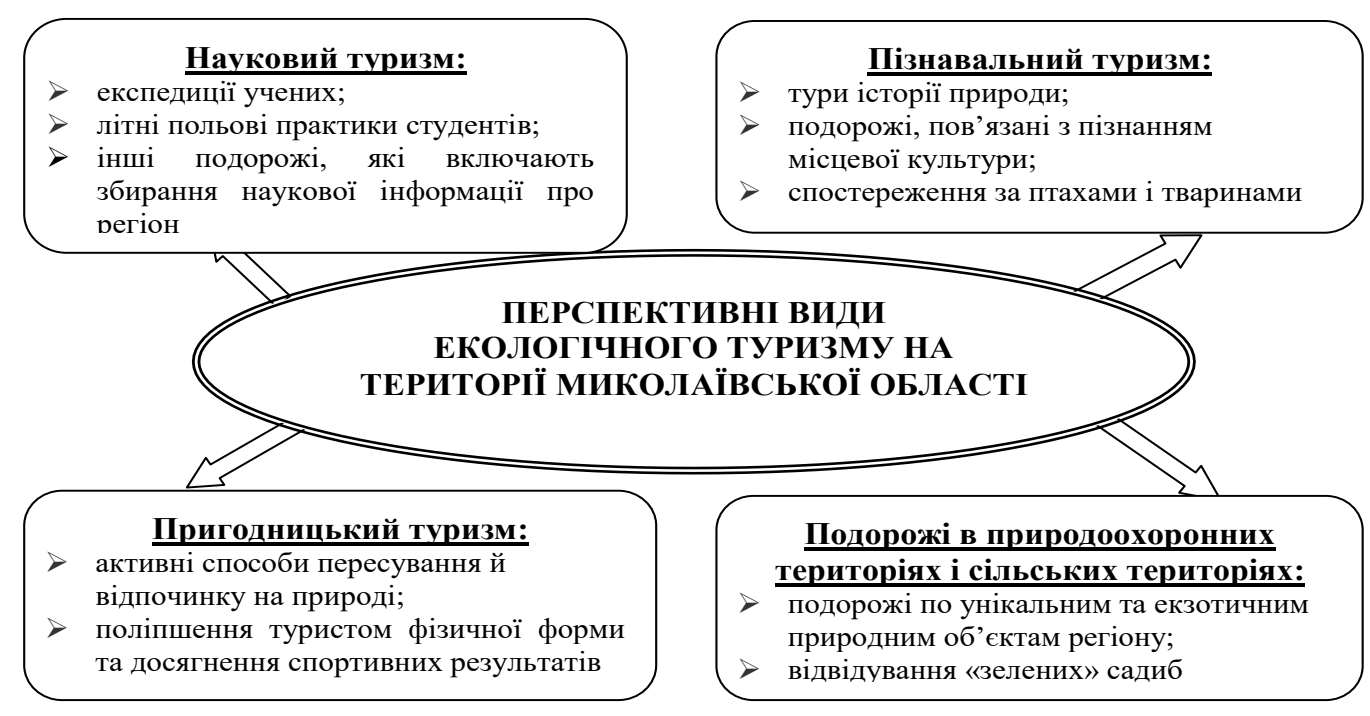

Рис. 1. Перспективні види екологічного туризму на території Миколаївської області 
порівняно із середніми показниками по Україні ціни на розміщення туристів у Миколаївській області у 1,8 разів менше у юридичних осіб і в 1,5 рази менше у фізичних осіб - підприємців.

Сучасні готелі мають створювати комфортабельні умови для відпочинку туристів і надавати низку додаткових послуг. Будівля готелю є багатофункціональною спорудою та має технологічно складне устаткування. Щодо екологічності комплекс будівель має органічно вписуватися в навколишнє середовище, зберігаючи особливості міського або сільського ландшафту. Слід враховувати природно-кліматичні чинники, температуру й вологість повітря, кількість опадів, швидкість і напрям вітру тощо. Готелі, кемпінги або табори, в яких зупиняються екотуристи, розташовуються так, щоб не порушувати екологічно сталий розвиток навколишнього ландшафту, й мають бути побудовані з матеріалів, які не зможуть завдати шкоди довкіллю. Будинки мають відповідати естетичним, технічним, санітарногігієнічним, екологічним нормам.

Однією із сучасних тенденцій розвитку готельного господарства є створення екоготелів. Міжнародна еко-

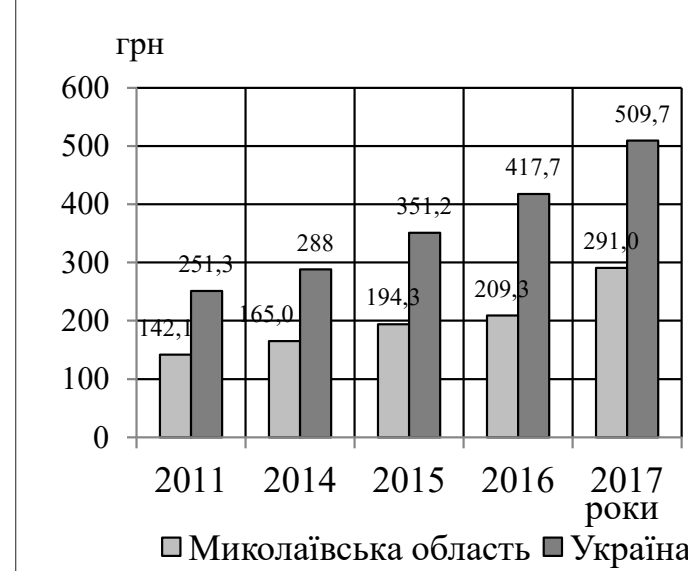

Юридичні особи

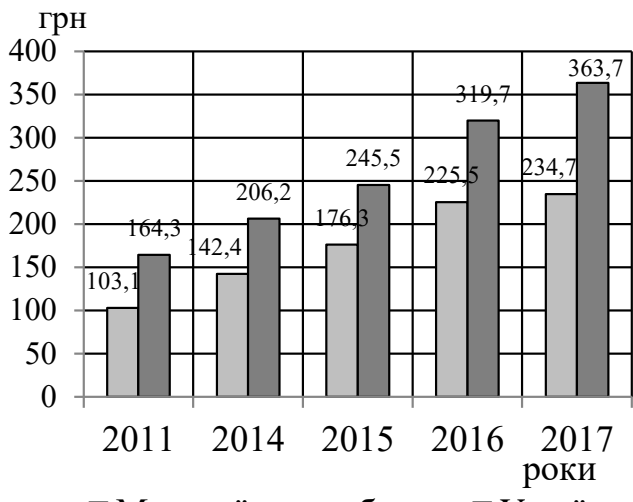

$\square$ Миколаївська область $\square$ Україна

Фізичні особи-підприємці

Рис. 2. Динаміка фактичних витрат на проживання в готелях

та спеціалізованих засобах розміщування (людино-день) у Миколаївській області та Україні

Таблиця 2

Структура колективних засобів розміщування у сфері надання туристичних послуг у Миколаївській області станом на 1 січня 2018 р.

\begin{tabular}{|c|c|c|c|c|c|}
\hline \multirow{2}{*}{ Засіб розміщування } & \multicolumn{2}{|c|}{ Кількість одиниць } & \multirow{2}{*}{$\begin{array}{c}\text { Питома вага } \\
\text { у загальній } \\
\text { кількості засобів } \\
\text { розміщування, \% }\end{array}$} & \multicolumn{2}{|c|}{$\begin{array}{c}\text { Середня вартість за один день } \\
\text { перебування, грн. }\end{array}$} \\
\hline & $\begin{array}{l}\text { юридичні } \\
\text { особи }\end{array}$ & $\begin{array}{l}\text { фізичні особи } \\
\text { - підприємці }\end{array}$ & & $\begin{array}{l}\text { юридичні } \\
\text { особи }\end{array}$ & $\begin{array}{l}\text { фізичні особи - } \\
\text { підприсмці }\end{array}$ \\
\hline $\begin{array}{l}\text { Всього колективних засобів } \\
\text { розміщування }\end{array}$ & 114 & 157 & 100 & 291,0 & 234,7 \\
\hline $\begin{array}{l}\text { Готелі та аналогічні об’єкти, } \\
\text { всього }\end{array}$ & 23 & 56 & 29,2 & 421,0 & 338,7 \\
\hline зокрема, готелі & 19 & 41 & 22,1 & 434,1 & 438,8 \\
\hline мотелі & - & 2 & 0,7 & - & 221,0 \\
\hline хостели & - & 1 & 0,4 & - & 120,0 \\
\hline кемпінги & - & 1 & 0,4 & - & 700,0 \\
\hline гуртожитки для приїжджих & 1 & & 0,4 & 718,7 & - \\
\hline $\begin{array}{l}\text { туристські бази, студентські } \\
\text { літні табори }\end{array}$ & 3 & 11 & 5,2 & 179,9 & 165,7 \\
\hline $\begin{array}{l}\text { Спеціалізовані засоби } \\
\text { розміщення, всього }\end{array}$ & 91 & 101 & 70,8 & 270,9 & 190,3 \\
\hline зокрема, санаторії & 3 & - & 1,1 & 338,8 & - \\
\hline дитячі санаторії & 5 & - & 1,8 & 270,0 & - \\
\hline пансіонати з лікуванням & 1 & - & 0,4 & - & - \\
\hline санаторії-профілакторії & 5 & - & 1,8 & 469,2 & - \\
\hline пансіонати відпочинку & 6 & 5 & 4,1 & 348,9 & 577,2 \\
\hline бази відпочинку & 71 & 96 & 61,6 & 205,1 & 179,9 \\
\hline
\end{tabular}


логічна програма “Green Key” («Зелений Ключ»), яка $\epsilon$ частиною Міжнародної Організації з екологічної освіти (Foundation for Environmental Education), проводить міжнародну екологічну сертифікацію готелів та туристичних об’єктів у більше ніж 25 країнах світу [9].

Деякі підприємства готельного господарства України вже пройшли екологічну сертифікацію “Green Кеу”. Один з таких готелів є "Reikartz Рівер", розташований в історичному центрі міста Миколаїва поряд 3 річкою Південний Буг. Для отримання «Зеленого Ключа» готель має дотримуватися низки вимог, які стосуються питань екологічного менеджменту, моніторингу та зменшення використання електроенергії, економного споживання водних ресурсів, сортування, переробки та утилізації відходів, участі у соціальному житті міста. Значною перевагою саме екосертифікації «Зелений Ключ» є наявність критеріїв, спрямованих на екологічне навчання, формування дружньої до довкілля свідомості гостей, співробітників та постачальників готелю [10].

Останніми роками число екотуристів зростає не тільки за рахунок збільшення потоку відвідувачів національних парків. Все більш популярним стає сільський (зелений) туризм, збільшується кількість екологічних турів до районів зі сприятливою й красивою природою, до місць розташування історико-культурних музеїв-заповідників, пам'яток природи та інших привабливих об'єктів.

Сьогодні в Миколаївській області нараховуються 74 об'єкти сільського (зеленого) туризму, найбільшими 3 яких є ферма «Саванна» (с. Ставки Веселинівського району); Страусина ферма «Кременівський страус» (c. Кременівка Веселинівського району); приватний комплекс рибалки і відпочинку «Золота підкова» (с. Кандибине Новоодеського району); Розважальний центр «Козацька застава» (смт Костянтинівка Арбузинського району). Найбільше об'єктів сільського (зеленого) туризму зосереджено у Березанському районі, а саме 41 об'єкт (55\%). Очаківський район представлений 10 сільськими садибами (14\%), Первомайський - 5 (7\%), Кривоозерський та Миколаївський має по 4 садиби (5\%), в інших районах розташовано по 1-2 об'єкти [11].

Формування інфраструктури екологічного туризму на сільських територіях може бути реалізовано через підприємницьку діяльність місцевих жителів, що забезпечить розвиток таких видів туризму, як кінний, водний, велосипедний, відвідування зелених садиб, збирання грибів, ягід тощо. Зазначені заходи сформують додатковий ринок збуту місцевої продовольчої продукції, нові робочі місця, дадуть змогу підвищити рівень матеріальної забезпеченості селян.

Крім того, розвиток сільського (зеленого) туризму спонукає до покращення благоустрою сільських садиб, вулиць, сіл загалом, стимулює розвиток місцевої соціальної інфраструктури, а саме будівництво доріг, водой газопроводів, очисних споруд, вирішення проблеми утилізації сміття [12].
Водночас потенційні можливості розвитку екологічного туризму в Миколаївській області використовуються не в повному обсязі. Ця проблема стає особливо актуальною у зв'язку зі зростанням потоку туристів на територіях природно-заповідного фонду. При цьому туристи стають більш вимогливими до рівня сервісу й комфортних умов проживання. Серед ключових чинників, що гальмують розвиток рекреаційної інфраструктури екологічного туризму на природоохоронних територіях, можна виділити такі:

- недостатня кількість міні-готелів і кемпінгів, що відповідають сучасним екологічним вимогам;

- недостатня кількість обладнаних екологічних стежок, місць для спостережень за тваринами та короткочасного відпочинку туристів тощо;

- обмежена інформація про можливості екологічного туризму на природоохоронних територіях (інформаційні дошки обов'язково мають містити списки видів рослин і тварин з коментарями, перелік рідкісних і зникаючих видів; обов'язковою $є$ наявність буклетів та інших освітніх матеріалів щодо пропаганди дбайливого ставлення до природи);

- низький рівень забезпеченості автомобільних доріг інформаційними та рекламними щитами щодо розташування об'єктів екологічного туризму;

- відсутність комфортних умов для всіх учасників дорожнього руху, зокрема велосипедистів;

- невідповідність ціни якості наданих послуг, що пропонуються в національних парках та інших природних об'єктах;

- відсутність економічних стимулів у співробітників природних заповідників і національних парків;

- відсутність спеціалізованих туристичних компаній, спрямованих на екологічні тури.

Ще одним важливим аспектом сучасної концепції екологічного туризму є питання, пов'язані з використанням більш екологічно чистих видів транспорту, поновлюваних джерел енергії, енерго- та ресурсозбереженням, безпечним видаленням відходів. Має приділятися велика увага створенню вільних від автомобілів туристських центрів і стимулюванню задля цього застосування нових форм доставки туристів.

Розвиток екологічного туризму сприяє збільшенню внутрішніх інвестицій. Дохід, що отримується від надання послуг туристам, $є$ джерелом формування й підтримки рекреаційної інфраструктури. Підвищити попит на екологічний туризм на природоохоронних територіях можна шляхом підготовки кадрів, які вміють проводити маркетингові дослідження. Наявність таких фахівців у штаті національних парків і заповідників дала б змогу підвищити якість продуктів екологічного туризму та задоволеність відвідувачів.

Висновки. Миколаївщина належить до областей, у яких туризм розглядається як один зі стратегічних напрямів регіонального розвитку. Раціональне використання природних і культурно-історичних ресурсів дасть змогу уникнути багатьох негативних наслідків масового туризму, а доходи від еколого-туристичної 
діяльності зроблять значний внесок у соціально-економічний розвиток регіону.

Пріоритетними завданнями розвитку інфраструктури екологічного туризму в Миколаївській області є:

- розширення мережі національних природних і регіональних ландшафтних парків, модернізація їх інфраструктури задля забезпечення бази для розвитку екологічного туризму в регіоні;

- державне регулювання еколого-туристичної діяльності, розроблення відповідних нормативних актів, впровадження та реалізація науково обгрунтованих національних і регіональних програм з екологічного туризму;

- співпраця регіональної влади та місцевого співтовариства задля формування рекреаційної інфраструктури, що відповідає міжнародним стандартам, сприяє економічному процвітанню регіону, вирішуючи завдання охорони навколишнього середовища;

- залучення вітчизняних та іноземних інвестицій;

- формування системи моніторингу рекреаційного навантаження задля недопущення нанесення шкоди природним комплексам та об'єктам.

Якісний стан природно-рекреаційних ресурсів, достатній рівень розвитку транспортної та сервісної інфраструктури під час використання гнучкої цінової політики дасть змогу активно просувати широкий асортимент продуктів екологічного туризму, що буде сприяти соціально-економічному розвитку регіону та збереженню його екологічної рівноваги.

\section{Список літератури:}

1. Québec Declaration on Ecotourism. Québec City, Canada, 22 May 2002. URL: https://www.gdrc.org/uem/eco-tour/ quebec-declaration.pdf (дата звернення: 22.02.2020).

2. Положення про рекреаційну діяльність у межах територій та об'єктів природно-заповідного фонду України : Наказ Міністерства охорони навколишнього природного середовища України від 22 червня 2009 p. № 330. URL: http://zakon.rada.gov.ua/laws/show/z0679-09 (дата звернення: 23.02.2020).

3. Екологічний паспорт Миколаївської області за 2018 p. URL: http://ecolog.mk.gov.ua/ua/ecoreports/ecopassport (дата звернення: 23.02.2020).

4. Про природно-заповідний фонд України : Закон України від 16 червня 1992 року № 2457-XII. URL: https://zakon.rada.gov.ua/laws/show/2456-12 (дата звернення: 23.02.2020).

5. Регіональна доповідь про стан навколишнього природного середовища в Миколаївській області у 2018 р. / Управління екології та природних ресурсів Миколаївської обласної державної адміністрації. Миколаїв, 2019. 175 с.

6. Програми розвитку туристичної галузі міста Миколаєва до 2020 р. : Рішення Миколаївської міської ради від 14 березня 2019 р. № 51/4. URL: https://mkrada.gov.ua/documents/31131.html (дата звернення: 26.02.2020).

7. Greenways в Україні. URL: http://www.greenways.com.uа (дата звернення: 24.02.2020).

8. Колективні засоби розміщування в Україні у 2017 році : статистичний збірник / Державна служба статистики України. Київ, 2018. 142 с.

9. Green Key. URL: http://www.greenkey.org/Menu/Criteria/Hotels (дата звернення: 24.02.2020).

10. Програма розвитку туризму та курортів у Миколаївській області на 2016-2020рр. : Рішення обласної ради від 10 червня 2016 р. № 6. Миколаїв, 2016. 16 с.

11. Загорянська О.Л. Оцінка конкурентоспроможності екологічних готелів у сучасних умовах господарювання. Глобальні та національні проблеми економіки. 2018. № 22. С. 662-668.

12. Нещадим Л.М. Розвиток зеленого туризму як фактора покращення соціальної сфери Черкаського регіону. Журнал Європейської економіки. 2015. Т. 14. № 4. С. 400-407.

\section{References:}

1. Québec Declaration on Ecotourism. Québec City, Canada, 22 May 2002. Available at: https://www.gdrc.org/uem/ecotour/quebec-declaration.pdf (accessed: 22.02.2020).

2. Polozhennia pro rekreatsiinu diialnist $\mathrm{u}$ mezhakh terytorii ta obiektiv pryrodno-zapovidnoho fondu Ukrainy. Nakaz Ministerstva okhorony navkolyshnoho pryrodnoho seredovyshcha Ukrainy № 330 vid 22.06.2009 [Regulations on recreational activities within the territories and objects of the Nature-Preservation Fund of Ukraine. Order of the Ministry of Environmental Protection of Ukraine No. 330 of 22.06.2009]. Available at: http://zakon.rada.gov.ua/laws/show/z0679-09 (accessed: 23.02.2020).

3. Ekolohichnyi pasport Mykolaivskoi oblasti za 2018 r. [Ecological passport of Mykolaiv region for 2018]. Available at: http://ecolog.mk.gov.ua/ua/ecoreports/ecopassport (accessed: 23.02.2020).

4. Pro pryrodno-zapovidnyi fond Ukrainy : Zakon Ukrainy vid 16.06.92 № 2457-XII [The Nature-Preservation Fund of Ukraine. Law of Ukraine No. 2457-XII of 16.06.92]. Available at: https://zakon.rada.gov.ua/laws/show/2456-12 (accessed: 23.02.2020).

5. Rehionalna dopovid pro stan navkolyshnoho pryrodnoho seredovyshcha v Mykolaivskii oblasti u 2018 r. Upravlinnia ekolohii ta pryrodnykh resursiv Mykolaivskoi oblasnoi derzhavnoi administratsii [Regional report on the state of the environment in Mykolaiv region in 2018. Management of ecology and natural resources of the Nikolaev regional state administration]. Mykolaiv (in Ukrainian).

6. Prohramy rozvytku turystychnoi haluzi mista Mykolaieva do 2020 r. Rishennia Mykolaivskoi miskoi rady vid 14.03.2019 № 51/4 [Programs of development of the tourist industry of the city of Nikolaev till 2020. The decision of 
the Nikolaev City Council No. 51/4 of 14.03.2019]. Available at: https://mkrada.gov.ua/documents/31131.html (accessed: 26.02.2020).

7. Greenways v Ukraini [Greenways in Ukraine]. Available at: http://www.greenways.com.ua (accessed: 24.02.2020).

8. Kolektyvni zasoby rozmishchuvannia v Ukraini u 2017 r. Statystychnyi zbirnyk. Derzhavna sluzhba statystyky Ukrainy [Collective accommodation facilities in Ukraine in 2017. Statistical collection. State Statistics Service of Ukraine]. Kiev (in Ukrainian).

9. Green Key. Available at: http://www.greenkey.org/Menu/Criteria/Hotels (accessed: 24.02.2020).

10. Prohrama rozvytku turyzmu ta kurortiv u Mykolaivskii oblasti na 2016-2020 roky. Rishennia oblasnoi rady vid 10.06.2016 № 6. [Program of development of tourism and resorts in Mykolaiv region for 2016-2020. Decision of the Regional Council No. 6 of 10.06.2016]. Mykolaiv (in Ukrainian).

11. Zahorianska O.L. (2018) Otsinka konkurentospromozhnosti ekolohichnykh hoteliv u suchasnykh umovakh hospodariuvannia [Evaluation of competitiveness of green hotels in modern conditions of economy]. Global and national problems of economy, no. 22, pp. 662-668.

12. Neshchadym L.M. (2015) Rozvytok zelenoho turyzmu yak faktora pokrashchennia sotsialnoi sfery Cherkaskoho rehionu [Development of green tourism as a factor of improvement of social sphere of Cherkasy region]. Journal of the European Economy, vol. 14, no. 4, pp. 400-407.

\section{ФОРМИРОВАНИЕ ИНФРАСТРУКТУРЫ ЭКОЛОГИЧЕСКОГО ТУРИЗМА В НИКОЛАЕВСКОЙ ОБЛАСТИ}

Статья посвящена исследованию особенностей формирования инфраструктуры экологического туризма в Николаевской области. Приведен перечень показателей, определяющих состояние и уровень развития рекреационной инфраструктуры экологического туризма в регионе. Потенцииальным ресурсом развития экологического туризма в Николаевской области является наличие начиональных природных и региональных ландшафтных парков. Определены факторы, обуславливающие развитие экологического туризма и его инфраструктуры в зонах рекреации природоохранных территорий. Проведен анализ структуры коллективньх средств размещения в сфере туристического бизнеса в Николаевской области, определены наиболее приемлемые средства размещения для сторонников экологического туризма по соотношению «иена - качество». Определены главные факторы, тормозящие развитие рекреационной инфраструктуры экологического туризма на природоохранньх территориях региона. Обоснованы приоритетные задания развития инфраструктуры экологического туризма в Николаевской области, направленные на сочиально-экономическое развитие региона и сохранение экологического равновесия.

Ключевые слова: экологический туризм, рекреационная инфраструктура, природно-заповедный фонд, национальные природные парки, региональные ландшафтные парки, сельский (зеленый) туризм, экоотели.

\section{FORMATION OF ECOLOGICAL TOURISM INFRASTRUCTURE IN MYKOLAIV REGION}

The article is dedicated to the research of ecological tourism infrastructure formation characteristics in Mykolaiv region. The list of indicators that determine the state and level of eco-tourism recreational infrastructure development in the region has been provided. The Mykolaiv region has a favorable geopolitical position for the development of ecological tourism. A potential resource for the development of eco-tourism in the Mykolaiv region is the presence of national nature parks and regional landscape parks. The recreational functions of the nature reserve territories and objects have been substantiated and their role in the development of ecological tourism has been determined. A brief description of the nature reserve territories of the Mykolaiv region has been given. There are four types of ecological tourism that are promising for the natural conditions of the Mykolaiv region: scientific tourism, cognitive tourism, adventure tourism, trips within nature reserve areas and rural areas. The structure of collective accommodation facilities in the sphere of providing tourist services in the Mykolaiv region is analyzed. The most appropriate means of accommodation of tourists according to the price - quality ratio are selected for the active forms of ecotourism. The dynamics of actual costs of hotel accommodation and specialized accommodation in the Mykolaiv region and Ukraine for 2011-2017 have been investigated. Modern environmental requirements for hotels have been reviewed. Buildings must meet aesthetic, technical, sanitary and environmental standards. The processes of ecological tourism infrastructure formation in rural territories of the Mykolaiv region have been reviewed. The popularity of rural (green) tourism is increasing every year. This creates an additional sales market for the realization of local food products, new jobs, and increases the level of financial support of the rural area residents. The main factors hindering the development of recreational infrastructure of eco-tourism in nature reserve areas of the region have been identified. Priority tasks of ecological tourism infrastructure development in the Mykolaiv region, which are aimed at social and economic development of the region and preservation of ecological balance, have been substantiated.

Key words: ecological tourism, recreational infrastructure, nature reserve territories, national nature parks, regional landscape parks, rural (green) tourism, eco-hotels. 